INDONESIA ACCOUNTING JOURNAL

VOLUME 2, NUMBER 1, YEAR 2020

Jurusan Akuntansi

Fakultas Ekonomi dan Bisnis

Universitas Sam Ratulangi

Jl. Kampus UNSRAT

Manado, Indonesia, 95115

${ }^{2,3}$ Jurusan Akuntansi

Fakultas Ekonomi dan Bisnis

Universitas Sam Ratulangi

Jl. Kampus UNSRAT

Manado, Indonesia, 95115

Article info:

Received 21 January 2020

Accepted 21 January 2020

Available online 21 January 2020

Keywords: diferential accounting information; decision making; special order

JEL Classification: M11, M13

DOI: http://doi.org/10.32400/iaj.27488

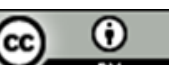

${ }^{1}$ Corresponding author

E-mail: reginapinontoan@gmail.com

\section{Penerapan informasi akuntansi diferensial dalam pengambilan keputusan manajemen pada UMKM Gilingan Padi Mekar Sari Desa Kosio Kecamatan Dumoga Tengah?}

\author{
Regina Firelsa Pinontoan ${ }^{1}$ \\ Sifrid Sonny Pangemanan ${ }^{2}$ \\ Treesje Runtu ${ }^{3}$
}

\begin{abstract}
Differential accounting information is one of the information needed by the management of a company in planning and decision making, especially accept or reject for special orders, which will help management in this case UMKM Gilingan Padi Mekar Sari which often get special orders. The purpose of this study was to determine the application of differential accounting information in the decision to accept or reject special orders to produce superwin rice and ciherang rice types at UMKM Gilingan Padi Mekar Sari. The method used in this research is descriptive qualitative. The results of this study can be seen based on the comparative calculation of regular production and special order production using the differential accounting information of the UMKM Gilingan Padi Mekar Sari in receiving special orders for both products namely superwin rice and ciherang rice will get an additional total differential profit of $\mathrm{Rp}$ 43.441.50o. Therefore, the use of differential accounting information is needed in the decision to accept or reject special orders.
\end{abstract}

\section{Pendahuluan}

Dalam perusahaan peran manajer dibutuhkan untuk mengatur seluruh kegiatan perusahaan dengan perencanaan untuk mencapai tujuan perusahaan. Sehingga manajemen perlu mengambil kebijakan atau tindakan yang ditopang dengan informasi yang benar yaitu data-data perusahaan yang umumnya terbagi dalam dua informasi yaitu informasi kualitatif dan informasi kuantitatif. Salah satu bentuk dari informasi kuantitatif ialah informasi akuntansi manajemen yang terdiri dari tiga tipe yaitu: (1) informasi akuntansi penuh, (2) informasi akuntansi pertanggungjawaban, dan (3) informasi akuntansi diferensial. Informasi akuntansi diferensial dalam penerapannya, dapat membantu pihak manajemen dalam kepastian memilih suatu alternatif yang relevan untuk menghadapi masalah perusahaan ataupun peluang yang mungkin terjadi dimasa mendatang.
Beberapa implementasi dari informasi akuntansi diferensial salah satunya menerima atau menolak pesanan khusus sebagai pertimbangan, apakah dengan keputusan menerima pesanan khusus tersebut akan menghasilkan laba yang lebih besar atau menolaknya.

UMKM Gilingan Padi Mekar Sari Desa Koio Kecamatan Dumoga Tengah sering menghadapi kondisi menerima atau menolak pesanan khusus untuk memproduksi beras superwin dan beras ciherang. Perusahaan tidak melakukan perincian biaya secara terstruktur untuk mengetahui perbedaan biaya atau laba yang akan dihasilkan atas pesanan khusus. Sehingga pemilik UMKM Gilingan Padi Mekar Sari membutuhkan informasi akuntansi diferensial untuk memperoleh perbandingan perhitungan sebagai bahan pertimbangan dalam pengambilan keputusan menerima atau menolak pesanan khusus untuk 
memproduksi beras superwin dan beras ciherang yang bertujuan untuk meningkatkan laba serta demi kemajuan perusahaan.

\section{Tinjauan pustaka}

$\begin{array}{ccr}\text { Konsep } & \text { akuntansi. } & \text { Akuntansi } \\ \text { rupakan } & \text { suatu } & \text { proses }\end{array}$ identifikasi/pengenalan, pengukuran dan pelaporan ekonomi. Informasi ekonomi yang dihasilkan oleh akuntansi diharapkan berguna untuk penilaian dan pengambilan keputusan bagi pihak yang memerlukan (The dan Sugiono, 2015:3). Sodikin dan Riyono (2014:2) menyatakan bahwa akuntansi dapat diklasifikasi menjadi akuntansi keuangan dan akuntansi manajemen.

Konsep akuntansi manajemen. Akuntansi manajemen merupakan bidang akuntansi yang berfokus pada penyediaan, termasuk pengembangan dan penafsiran informasi akuntansi bagi para manajer untuk digunakan sebagai bahan perencanaan, pengendalian operasi, dan dalam pengambilan keputusan (Samryn 2015:4).

Konsep akuntansi biaya. Mulyadi (2014:7) menyatakan bahwa akuntansi biaya adalah proses pencatatan, penggolongan, peringkasan dan penyajian biaya, pembuatan dan penjualan produk, dengan cara tertentu, serta penafsiran terhadapnya. Sujarweni (2018:9) menyatakan bahwa biaya dalam arti luas adalah pengorbanan sumber ekonomi yang diukur dalam satuan uang dalam usahanya untuk mendapatkan sesuatu untuk mencapai tujuan tertentu baik yang sudah terjadi dan belum terjadi/baru direncanakan, sedangkan biaya dalam arti sempit adalah pengorbanan sumber ekonomi dalam satuan uang untuk memperoleh aktiva. Metode pengumpulan biaya produksi terdiri dari dua kelompok yaitu: (1) biaya produksi merupakan biaya-biaya yang dikeluarkan dalam pengolahan bahan baku menjadi produk, dan (2) biaya non-produksi merupakan biaya-biaya yang dikeluarkan untuk kegiatan non-produksi, seperti kegiatan pemasaran dan kegiatan administrasi dan umum. Metode penentuan biaya produksi terdiri dari dua pendekatan yaitu: (1) full costing merupakan metode penentuan kos produksi yang memperhitungkan semua unsur biaya produksi ke dalam kos produksi, yang terdiri dari biaya bahan baku, biaya tenaga kerja langsung, dan biaya overhead pabrik, baik berperilaku variabel maupun tetap, dan (2) variable costing merupakan metode penentuan kos produksi yang hanya memperhitungkan biaya produksi yang berperilaku variabel ke dalam kos produksi, terdiri dari biaya bahan baku, biaya tenaga kerja langsung dan biaya overhead pabrik variabel (Mulyadi 2014:17).

Informasi akuntansi manajemen. Informasi akuntansi manajemen adalah suatu sistem yang diperoleh dari data-data suatu perusahaan atau entitas dibuat menjadi informasi yang mampu membantu pihak manajemen dalam pengambilan keputusan. Sujarweni (2016:6) menyatakan bahwa informasi akuntansi manajemen digunakan oleh pimpinan perusahaan untuk menunjang pelaksanaan fungsi-fungsi manajemen, khususnya fungsi perencanaan dan pengawasan. Salman dan Farid (2016:9) menyatakan bahwa informasi akuntansi manajemen dapat dihubungkan dengan tiga hal: obyek informasi (produk, departemen, aktivitas) alternatif yang akan dipilih dan wewenang manajer. Oleh karena itu, informasi akuntansi manajemen dibagi menjadi tiga tipe informasi, yaitu informasi akuntansi penuh (full accounting information), informasi akuntansi diferensial (differential accounting information), dan informasi akuntansi pertanggungjawaban (responbility accounting information).

Informasi akuntansi diferensial. Informasi akuntansi diferensial merupakan infomasi yang dibuat untuk memilih salah satu alternatif pilihan pada perusahaan. Rachmina dan Sari (2017:148) menyatakan bahwa informasi akuntansi diferensial membantu manajemen dalam pengambilan keputusan berkaitan dengan informasi yang akan datang. Pemilihan berbagai alternatif yang masing-masing memiliki perbedaan yang akan menimbulkan pengaruh terhadap kinerja perusahaan yang akan datang. Halim 
et al. (2013:10) menyatakan bahwa informasi akuntansi diferensial menyajikan informasi taksiran biaya, pendapatan dan aktiva berbeda jika suatu tindakan tertentu dipilih, dibandingkan dengan alternatif tindakan lain.

$\begin{array}{llr}\begin{array}{c}\text { Manfaat } \\ \text { diferensial }\end{array} & \text { informasi } & \begin{array}{r}\text { akuntansi } \\ \text { dalam }\end{array} \\ \text { keputusan } & \text { manajemen. } & \text { Sodikin }\end{array}$
(2015:133) menyatakan bahwa analisis diferensial (differential analysis) adalah sebuah model keputusan yang dapat digunakan untuk mengevaluasi perbedaan-perbedaan dalam pendapatan dan biaya yang berkaitan dengan pelbagai alternatif tindakan. Hansen dan Mowen (2016:74) menyatakan bahwa ada beberapa manfaat informasi akuntansi diferensial dalam pengambilan keputusan yang dihadapi oleh pihak manajemen atau pengelola perusahaan yaitu: (1) keputusan membuat atau membeli (make-or-buy decision), (2) keputusan meneruskan atau menghentikan (keep-or-drop decision), (3) keputusan pesanan khusus (special-order decision), dan (4) keputusan menjual atau memproses lebih lanjut (sell-or-process further).

Pesanan khusus. The dan Sugiono (2015:123) menyatakan bahwa pesanan khusus adalah penjualan harganya dibawah dari harga pasaran karena perusahaan menggunakan kapasitasnya yang menganggur (idle capacity). Pesanan khusus dapat diterima apabila menambah laba perusahaan dan sebaliknya ditolak apabila mengurangi laba perusahaan. Untuk menentukan pesanan khusus diterima atau ditolak harus menggunakan pendekatan langsung (direct costing) dimana seluruh biaya tetap dinyatakan sebagai beban. Dengan demikian, yang dimaksud dengan biaya produksi adalah hanya terdiri dari biaya variabel (bahan baku langsung, tenaga kerja langsung, dan biaya overhead variabel).

Penelitian terdahulu. Anggraini et al., (2015) menunjukkan bahwa dengan menerima pesanan khusus akan memperoleh tambahan laba. Longdong dan Tirayoh (2014) menunjukkan bahwa dengan menerima pesanan khusus perusahaan dapat memperoleh laba yang lebih tinggi.
Kusumawati et al., (2014) menunjukkan bahwa analisis biaya diferensial yang diterapkan dengan menerima pesanan khusus dapat memaksimalkan kapasitas produksi perusahaan serta tambahan laba. Ticoalu et al., (2014) menunjukkan bahwa biaya-biaya yang relevan dengan pesanan khusus dapat meningkatkan laba perusahaan.

\section{Metode penelitian}

Penelitian menggunakan pendekatan kualitatif dengan metode deskriptif. Penelitian ini dimaksudkan untuk menganalisis masalah dengan cara mendeskripsikan pada data-data yang sudah ada, yang dapat memberikan gambaran maupun uraian secara jelas. Jenis data yang digunakan pada penelitian ini adalah data kualitatif berupa penjelasan mengenai gambaran umum UMKM Gilingan Padi Mekar Sari dan data kuantitatif berupa dokumentasi data biaya produksi dan data penjualan dari UMKM Gilingan Padi Mekar Sari tahun 2018 yang diperoleh dari data primer, sedangkan metode pengumpulan data yang digunakan berupa wawancara dan dokumentasi. Metode analisis data yang digunakan dalam penelitian ini adalah metode deskriptif, yaitu data dan informasi dikumpulkan dengan maksud membahas serta menguraikan permasalahan yang ada dalam perusahaan secara terperinci dan terstruktur hingga menghasilkan solusi untuk jawaban atas permasalahan yang dapat ditarik sebagai kesimpulan. Proses analisis yang dilakukan pada langkah-langkah sebagai berikut:

1. Mempelajari kegiatan produksi, kegiatan penyedian bahan baku, kegiatan penyediaan tenaga kerja dan fasilitas pabrik untuk proses produksi.

2. Mengumpulkan dokumen-dokumen yang diperlukan seperti data biaya produksi dan penjualan beras superwin dan beras ciherang dari UMKM Gilingan Padi Mekar Sari tahun 2018.

3. Menganalisa perhitungan biaya produksi yang diterapkan di UMKM Gilingan Padi Mekar Sari dalam pengambilan 
keputusan menerima dan menolak pesanan khusus untuk memproduksi jenis beras superwin dan jenis beras ciherang.

4. Melakukan perhitungan harga pokok produksi reguler dan perhitungan harga pokok produksi dengan pesanan khusus di UMKM Gilingan Padi Mekar Sari.

5. Melakukan perbandingan perhitungan produksi reguler dan perhitungan pesanan khusus jenis beras superwin dan jenis beras ciherang UMKM Gilingan Padi Mekar Sari.

\section{Hasil penelitian pembahasan \\ Hasil penelitian}

Produk beras yang diproduksi di UMKM Gilingan Padi Mekar Sari yang akan dibahas yaitu beras superwin dan beras ciherang yang merupakan jenis beras yang paling tinggi penjualannya. Untuk menghasilkan produk jadi beras membutuhkan waktu sekitar 150-152 hari dari proses mengolah lahan sawah hingga proses mengemas. UMKM Gilingan Padi Mekar Sari dalam kegiatan memproduksi beras dari proses menanam hingga proses mengemas tergolong dalam biaya produksi dan biaya non-produksi. Biaya produksi terdiri dari 3 jenis elemen biaya yang harus dikeluarkan yaitu biaya bahan baku, biaya tenaga kerja langsung dan biaya overhead pabrik. Sedangkan biaya non-produksi yaitu biaya pemasaran. Berikut adalah data produksi dan penjualan beras reguler dengan kemasan per unit $60 \mathrm{~kg}$ selama tahun 2018 .

Tabel 1. Data produksi dan penjualan beras

\begin{tabular}{lccc}
\hline $\begin{array}{c}\text { Jenis } \\
\text { Beras }\end{array}$ & $\begin{array}{c}\text { Unit } \\
\text { Produksi } \\
(\mathbf{6 0} \\
\mathbf{k g} / \mathbf{k a r u n g})\end{array}$ & $\begin{array}{c}\text { Harga } \\
\text { Jual } \\
\text { per Unit } \\
\mathbf{( R \mathbf { p } )}\end{array}$ & $\begin{array}{c}\text { Penjualan } \\
\mathbf{( R p )}\end{array}$ \\
\hline Superwin & 356 & 600.000 & 213.600 .000 \\
Ciherang & 194 & 580.000 & 112.520 .000 \\
\hline Total & $\mathbf{5 5 0}$ & $\mathbf{1 . 1 8 0 . 0 0 0}$ & $\mathbf{3 2 6 . 1 2 0 . 0 0 0}$ \\
\hline Sumber: UMKM Gilingan Padi Mekar Sari, 2018
\end{tabular}

Tabel 1 menunjukkan bahwa selama tahun 2018 UMKM Gilingan Padi Mekar Sari memproduksi dua jenis beras, yaitu beras superwin dan beras ciherang dimana dalam kemasan per unit berisi $60 \mathrm{~kg}$ beras. Beras superwin diproduksi sebanyak 356 unit dengan harga jual per unit Rp 600.000 sehingga hasil penjualan beras superwin $\mathrm{Rp}$ 213.600.000. Sedangkan beras Ciherang diproduksi sebanyak 194 unit dengan harga jual Rp 580.000.000 sehingga berjumlah Rp 112.520.000. Jadi, total produksi adalah 544 unit beras dengan hasil penjualan sebesar Rp 326.120.000.

Tabel 2. Rincian biaya beras superwin dan beras ciherang tahun 2018

\begin{tabular}{|c|c|c|}
\hline Jenis Biaya & $\begin{array}{c}\text { Beras } \\
\text { Superwin } \\
(\mathbf{R p})\end{array}$ & $\begin{array}{c}\text { Beras } \\
\text { Ciherang } \\
(\mathbf{R p})\end{array}$ \\
\hline \multicolumn{3}{|l|}{ Biaya Produksi } \\
\hline Biaya Bahan Baku & 87.940 .000 & 43.670 .000 \\
\hline Biaya Tenaga Kerja & & \\
\hline Langsung & 62.800 .000 & 31.500 .000 \\
\hline \multicolumn{3}{|l|}{ Biaya Overhead Pabrik } \\
\hline Variabel & 7.411 .273 & 4.038 .727 \\
\hline Biaya Overbead Pabrik Tetap & 22.330 .909 & 12.169.091 \\
\hline \multicolumn{3}{|l|}{ Biaya Non-Produksi } \\
\hline Biaya Pemasaran & 4.595 .636 & 2.504 .364 \\
\hline Total & 185.077 .818 & 93.882 .182 \\
\hline
\end{tabular}

Tabel 2 menunjukkan bahwa total biaya untuk memproduksi jenis beras superwin diketahui harga pokok produk sebagai berikut.

$$
\begin{aligned}
\begin{array}{l}
\text { Harga } \\
\text { pokok } \\
\text { produk }
\end{array} & =\frac{\begin{array}{c}
\text { Total biaya beras } \\
\text { superwin }
\end{array}}{\begin{array}{c}
\text { Jumlah produksi } \\
\text { beras superwin }
\end{array}} \\
& =\frac{185.077 .818}{356} \\
& =\begin{array}{l}
\text { Rp } 519.881,5112 \text { dibulatkan } \\
\text { menjadi Rp } 520.000 .
\end{array}
\end{aligned}
$$

Jadi, harga pokok produk untuk jenis beras superwin adalah Rp 520.000/unit. Sehingga dengan harga jual Rp 600.000/unit UMKM Gilingan Padi Mekar Sari mendapatkan untung tiap unit berisi $60 \mathrm{~kg}$ beras superwin sebesar Rp 80.000. Dari Tabel 2 diketahui juga total biaya untuk memproduksi jenis beras ciherang diketahui harga pokok produk sebagai berikut. 


$$
\begin{aligned}
\begin{array}{c}
\text { Harga } \\
\text { pokok } \\
\text { produk }
\end{array} & =\frac{\begin{array}{c}
\text { Total biaya beras } \\
\text { ciherang }
\end{array}}{\begin{array}{c}
\text { Jumlah produksi } \\
\text { beras ciherang }
\end{array}} \\
& =\frac{93.882 .182}{194} \\
& =\begin{array}{l}
\text { Rp 483.928,7732 dibulatkan } \\
\text { menjadi Rp 484.000. }
\end{array}
\end{aligned}
$$

Jadi, harga pokok produk untuk jenis beras ciherang adalah Rp 484.000/unit. Sehingga dengan harga jual Rp 580.000/unit UMKM Gilingan Padi Mekar Sari mendapatkan untung tiap unit berisi $60 \mathrm{~kg}$ beras ciherang sebesar Rp 96.000.

Pesanan Khusus. UMKM Gilingan Padi Mekar Sari mendapatkan pesanan khusus beras superwin dan beras ciherang dari salah satu pelanggan. Pesanan khusus ini penawaran harga lebih rendah dari harga jual pada penjualan reguler. Berikut adalah data produksi pesanan khusus.

Tabel 3. Data produksi beras pesanan khusus

\begin{tabular}{lccr}
\hline $\begin{array}{c}\text { Jenis } \\
\text { Beras }\end{array}$ & $\begin{array}{c}\text { Unit } \\
\text { Produksi } \\
(\mathbf{6 0} \\
\mathbf{k g} / \mathbf{k a r u n g})\end{array}$ & $\begin{array}{c}\text { Harga } \\
\text { Jual } \\
\text { per Unit } \\
(\mathbf{R p})\end{array}$ & $\begin{array}{c}\text { Penjualan } \\
\text { (Rp) }\end{array}$ \\
\hline Superwin & 220 & 595.000 & 130.900 .000 \\
Ciherang & 96 & 575.000 & 55.200 .000 \\
\hline Total & $\mathbf{3 1 6}$ & $\mathbf{1 . 1 7 0 . 0 0 0}$ & $\mathbf{1 8 6 . 1 0 0 . 0 0 0}$ \\
\hline Sumber: Data diolah, 2019 & &
\end{tabular}

Berdasarkan Tabel 3 diketahui bahwa penawaran pesanan khusus beras superwin dengan harga Rp 595.000 per unit sebanyak 220 unit beras berjumlah Rp 130.900.000. Sedangkan penawaran pesanan khusus beras ciherang dengan harga Rp 575.000 per unit sebanyak 96 unit beras berjumlah $\mathrm{Rp}$ 55.200 .000 .
Tabel 4. Rincian biaya beras superwin dan beras ciherang pada pesanan khusus

\begin{tabular}{lcc}
\hline \multicolumn{1}{c}{ Jenis Biaya } & $\begin{array}{c}\text { Beras } \\
\text { Superwin } \\
(\mathbf{R p})\end{array}$ & $\begin{array}{c}\text { Beras } \\
\text { Ciherang } \\
(\mathbf{R p})\end{array}$ \\
\hline Biaya Produksi & & \\
$\begin{array}{l}\text { Biaya Bahan Baku } \\
\text { Biaya Tenaga Kerja }\end{array}$ & 54.962 .500 & 21.835 .000 \\
$\begin{array}{l}\text { Langsung } \\
\text { Biaya Overhead Pabrik }\end{array}$ & 39.150 .000 & 15.750 .000 \\
$\begin{array}{l}\text { Variabel } \\
\text { Biaya Non-Produksi }\end{array}$ & 5.102 .468 & 2.226 .532 \\
Biaya Pemasaran & & \\
\hline Total & 2.528 .608 & 1.103 .392 \\
\hline Sumber: Data diolah, 2019 & $\mathbf{1 0 1 . 7 4 3 . 5 7 6}$ & $\mathbf{4 0 . 9 1 4 . 9 2 4}$ \\
\hline
\end{tabular}

Tabel 4 menunjukkan bahwa total biaya untuk memproduksi jenis beras superwin pesanan khusus diketahui harga pokok produk sebagai berikut.

$$
\begin{aligned}
\underset{\begin{array}{c}
\text { Harga pokok } \\
\text { produk }
\end{array}}{ } & =\frac{\begin{array}{c}
\text { Total biaya beras } \\
\text { superwin }
\end{array}}{\begin{array}{c}
\text { Jumlah produksi } \\
\text { beras superwin }
\end{array}} \\
& =\frac{101.743 .576}{220} \\
& =\begin{array}{l}
\text { Rp 462.470,8 dibulatkan } \\
\text { menjadi Rp 462.500. }
\end{array}
\end{aligned}
$$

Jadi, harga pokok produk untuk jenis beras superwin pesanan khusus adalah $\mathrm{Rp}$ 462.500/unit. Sehingga dengan harga jual Rp 595.000/unit UMKM Gilingan Padi Mekar Sari mendapatkan untung tiap unit berisi $60 \mathrm{~kg}$ beras superwin sebesar $\mathrm{Rp}$ 132.500. Berdasarkan Tabel 4 diketahui bahwa total biaya untuk memproduksi jenis beras ciherang pesanan khusus diketahui harga pokok produk sebagai berikut.

$$
\begin{aligned}
\underset{\text { Harga pokok }}{\text { produk }} & =\frac{\begin{array}{c}
\text { Total biaya beras } \\
\text { ciherang }
\end{array}}{\begin{array}{c}
\text { Jumlah produksi } \\
\text { beras ciherang }
\end{array}} \\
& =\frac{40.914 .924}{96} \\
& =\begin{array}{l}
\text { Rp 426.197,125 dibulatkan } \\
\text { menjadi Rp 426.500. }
\end{array}
\end{aligned}
$$


Jadi, harga pokok produk untuk jenis beras ciherang pesanan khusus adalah $\mathrm{Rp}$ 426.500/unit. Sehingga dengan harga jual Rp 575.000/unit UMKM Gilingan Padi Mekar Sari mendapatkan untung tiap unit berisi $60 \mathrm{~kg}$ beras ciherang sebesar $\mathrm{Rp}$
148.500. Tabel 5 menunjukkan bahwa perbandingan perhitungan antara produksi reguler dengan pesanan khusus untuk kedua jenis beras yakni beras superwin dan beras ciherang.

Tabel 5. Perbandingan perhitungan produksi reguler dengan pesanan khusus beras superwin dan beras ciherang

\begin{tabular}{|c|c|c|c|c|c|c|c|}
\hline \multirow[b]{2}{*}{ Ket. } & \multicolumn{3}{|c|}{ Beras Superwin } & \multirow[b]{2}{*}{ Ket. } & \multicolumn{3}{|c|}{ Beras Ciherang } \\
\hline & $\begin{array}{l}\text { Produksi } \\
\text { Reguler } \\
\text { (Rp) }\end{array}$ & $\begin{array}{c}\text { Pesanan } \\
\text { Khusus (Rp) }\end{array}$ & $\begin{array}{l}\text { Diferensial } \\
\text { (Rp) }\end{array}$ & & $\begin{array}{l}\text { Produksi } \\
\text { Reguler } \\
\text { (Rp) }\end{array}$ & $\begin{array}{c}\text { Pesanan } \\
\text { Khusus } \\
\text { (Rp) }\end{array}$ & $\begin{array}{c}\text { Diferensial } \\
\text { (Rp) }\end{array}$ \\
\hline Penjualan & 213.600 .000 & & & Penjualan & 112.520 .000 & & 57.320 .000 \\
\hline $\begin{array}{l}\text { Reguler } \\
\text { Pendapatan }\end{array}$ & & & 82.700 .000 & $\begin{array}{l}\text { Reguler } \\
\text { Pendanatan }\end{array}$ & & & \\
\hline $\begin{array}{l}\text { Pendapatan } \\
\text { Diferensial }\end{array}$ & & 130.900 .000 & & Diferensial & & 55.200 .000 & \\
\hline $\begin{array}{l}\text { Biaya Bahan } \\
\text { Baku }\end{array}$ & 87.940 .000 & 54.962 .500 & 32.977 .500 & $\begin{array}{l}\text { Biaya Bahan } \\
\text { Baku }\end{array}$ & 43.670 .000 & 21.835 .000 & 21.835 .000 \\
\hline Biaya Tenaga & & & & Biaya Tenaga & & & \\
\hline Kerja & 62.800 .000 & 39.150 .000 & 23.650 .000 & Kerja & 31.500 .000 & 15.750 .000 & 15.750 .000 \\
\hline Langsung & & & & Langsung & & & \\
\hline Biaya Overhead & & & & Biaya Overbead & & & \\
\hline $\begin{array}{l}\text { Pabrik } \\
\text { Variabel }\end{array}$ & 7.411 .273 & 5.102 .468 & 2.308 .805 & $\begin{array}{l}\text { Pabrik } \\
\text { Variabel }\end{array}$ & 4.038 .727 & 2.226 .532 & 1.812 .195 \\
\hline $\begin{array}{l}\text { Biaya Overhead } \\
\text { Pabrik Tetap }\end{array}$ & 22.330 .909 & - & 22.330 .909 & $\begin{array}{l}\text { Biaya Overhead } \\
\text { Pabrik Tetap }\end{array}$ & 12.169 .091 & - & 12.169 .091 \\
\hline $\begin{array}{l}\text { Biaya } \\
\text { Pemasaran }\end{array}$ & 4.595 .636 & 2.528 .608 & 2.067 .028 & $\begin{array}{l}\text { Biaya } \\
\text { Pemasaran }\end{array}$ & 2.504 .364 & 1.103 .392 & 1.400 .972 \\
\hline Total Biaya & 185.077.818 & 101.743 .576 & 83.334 .242 & Total Biaya & 93.882 .182 & 40.914 .924 & 52.967 .258 \\
\hline Laba Bersih & 28.522 .182 & 29.156 .424 & 634.242 & Laba Bersih & 18.637 .818 & 14.285 .076 & 4.352 .742 \\
\hline
\end{tabular}

\section{Pembahasan}

Berdasarkan Tabel 5, laba bersih dari hasil penjualan produksi reguler jenis beras superwin sebesar Rp 28.522.182. Sedangkan jumlah pendapatan diferensial sebesar Rp 130.900.000 dan laba diferensial jenis beras superwin sebesar Rp 29.156.424. Laba bersih dari hasil penjualan produksi reguler jenis beras ciherang sebesar Rp 18.637.818. Sedangkan jumlah pendapatan diferensial adalah Rp 55.200.000 dan laba diferensial adalah $\mathrm{Rp}$ 14.285.076. Dengan menggunakan akuntansi diferensial dalam pengambilan keputusan menerima pesanan khusus, walaupun dengan penawaran harga jual yang dibawah dari harga jual produksi reguler, namun dapat menghasilkan total laba diferensial atas pesanan khusus beras superwin dan beras ciherang adalah sebesar Rp 43.441.500. Sehingga pemilik UMKM Gilingan Padi Mekar Sari selaku penanggungjawab penuh yang juga sebagai pengambil keputusan sebaiknya dalam memilih alternatif dengan mengambil keputusan untuk selalu menerima pesanan khusus untuk kedua jenis beras yaitu beras superwin dan beras ciherang karena dapat menciptakan laba untuk perusahaan. Dengan demikian, penerapan informasi akuntansi diferensial membantu perusahaan dalam hal ini UMKM Gilingan Padi Mekar Sari untuk lebih terperinci serta terstruktur dalam pengklasifikasian atas seluruh biayabiaya dalam proses produksi maupun nonproduksi sehingga memudahkan pemilik perusahaan dalam setiap pengambilan keputusan. Disamping itu, manfaat dari penggunaan informasi akuntansi diferensial khususnya dalam menerima pesanan khusus dapat menghasilkan tambahan laba selain dari produksi reguler serta dapat meningkatkan pengolahan lahan sawah secara maksimal dan meminimalisir kapasitas pabrik yang menggangur untuk keberlangsungan dan kemajuan perusahaan. 


\section{Kesimpulan dan saran \\ Kesimpulan}

Dari hasil penelitian dan pembahasan yang dilakukan mengenai penerapan informasi akuntansi diferensial dalam keputusan menerima atau menolak pesanan khusus pada UMKM Gilingan Padi Mekar Sari Desa Kosio Kecamatan Dumoga Tengah, maka dapat disimpulkan bahwa perusahaan tidak memiliki perincian biaya secara terstruktur serta tidak menerapkan informasi akuntansi diferensial yang dapat dipakai sebagai bahan pertimbangan untuk setiap pengambilan keputusan menerima atau menolak pesanan khusus. Berdasarkan perbandingan perhitungan produksi reguler dan perhitungan pesanan khusus menggunakan informasi akuntansi diferensial UMKM Gilingan Padi Mekar Sari dalam menerima pesanan khusus atas kedua produk yaitu beras superwin dan beras ciherang akan mendapatkan tambahan total laba diferensial sebesar Rp 43.441.500.

\section{Saran}

Sebaiknya UMKM Gilingan Padi Mekar Sari dapat menggunakan informasi akuntansi diferensial dalam memudahkan pengambilan keputusan untuk menerima atau menolak pesanan khusus, dimana perusahaan sering mendapatkan pesanan khusus untuk dua jenis beras superwin dan beras ciherang yang dapat menciptakan laba untuk perusahaan. Dengan mengambil keputusan menerima pesanan khusus diantara alternatif yang tersedia sehingga dapat memaksimalkan pengolahan lahan sawah serta meminimasilir kapasitas pabrik yang mengganggur dengan cara melakukan peningkatan tenaga kerja langsung maupun tenaga kerja tidak langsung.

\section{Daftar pustaka}

Anggraini, D. A., Dwiatmanto, \& Azizah, D. F. (2015). Analisis biaya diferensial untuk meningkatkan pendapatan studi kasus pada Usaha Medali Mas, Kota Kediri. Jurnal Administrasi Bisnis 26(1): 17.

http://administrasibisnis.studentjournal.ub.ac.id /index.php/jab/article/view/1024/1207

Halim, A., Supomo, B., \& Kusufi, M. S. (2013). Akuntansi manajemen. Yogyakarta: BPFE.

Hansen, D. R., \& Mowen, M. M. (2016). Akuntansi manajerial. Jakarta: Salemba Empat.

Kusumawati, D., Rahayu, S. M., \& Atmanto, D. (2014). Analisis biaya diferensial dalam rangka menerima atau menolak pesanan khusus studi pada Suksesabiz Store Konveksi dan Sablon, Sidoarjo. Jurnal Administrasi Bisnis 12(1): 1-10. http://administrasibisnis.studentjournal.ub.ac.id /index.php/jab/article/view/477/675

Longdong, E., \& Tirayoh, V. Z. (2014). Analisis penggunaan informasi akuntansi diferensial dalam pengambilan keputusan manajemen menerima atau menolak pesanan khusus pada Modern Taylor. Jurnal EMBA 2(3): 1112-1117. https://ejournal.unsrat.ac.id/index.php/emba/a rticle/view/5783/5316

Mulyadi. (2014). Akuntansi biaya. Yogyakarta: UPP STIM YPKN.

Rachmina, D., \& Sari, S. W. (2017). Akuntansi manajemen teori dan aplikasi. Jakarta: Polimedia Publishing.

Salman, K. R., \& Farid, M. (2016). Akuntansi manajemen alat pengukuran dan pengambilan keputusan manajerial. Jakarta: Indeks.

Samryn, L. M. (2015). Akuntansi manajemen informasi biaya untuk mengendalikan aktivitas operasi dan investasi. Jakarta: Prenadamedia Group.

Sodikin, S. S. (2015). Akuntansi manajemen. Yogyakarta: UPP STIM YPKN.

Sodikin, S. S. \& Riyono, B. A. (2014). Akuntansi pengantar 1. Yogyakarta: UPP STIM YPKN.

Sujarweni, V. W. (2016). Akuntansi manajemen teori dan aplikasi. Yogyakarta: Pustaka Baru Press.

Sujarweni, V. W. (2018). Akuntansi biaya. Yogyakarta: Pustaka Baru Press.

The, I., \& Sugiono, A. (2015). Akuntansi informasi dalam pengambilan keputusan. Jakarta: Grasindo.

Ticoalu, N., Nangoi, G. B., \& Walandouw, S. K. (2014). Penggunaan informasi akuntansi diferensial dalam pengambilan keputusan terhadap pesanan khusus pada UD. Vanela. Jurnal EMBA 2(1): 686-695. https://ejournal.unsrat.ac.id/index.php/emba/a rticle/view/4383/3912 